\begin{tabular}{|c|c|c|}
\hline \multirow{3}{*}{$\begin{array}{c}\text { Cellular Physiology } \\
\text { and Biochemistry }\end{array}$} & \multicolumn{2}{|c|}{ Cell Physiol Biochem 2012;30:1333-1339 } \\
\hline & $\begin{array}{l}\text { DOI: } 10.1159 / 000343322 \\
\text { Published online: October 23, } 2012\end{array}$ & $\begin{array}{l}\text { (c) } 2012 \text { S. Karger AG, Basel } \\
\text { www.karger.com/cpb }\end{array}$ \\
\hline & 17, 2012 & 1015-8987/12/0306-133 \\
\hline
\end{tabular}

\title{
Purinergic Signaling, Dyslipidemia and Inflammatory Disease
}

\author{
Daniel L. Sparks Cynthia Chatterjee
}

Atherosclerosis, Genetics and Cell Biology Group, University of Ottawa Heart Institute, Ottawa, ON, K1Y 4W7, Canada

\section{Key Words}

Nucleotides • Lipoprotein • Autophagy $•$ Inflammation $•$ Insulin receptor $•$ Purinergic signaling

\begin{abstract}
Metabolic syndrome is a compound obesity disorder, wherein the abnormal metabolism of glucose and lipid is associated with the development of chronic inflammatory diseases. The prevalence of this disease is increasing in the developed world, but the causative linkage between these metabolic disorders has remained obscure. Metabolic disease may be associated with chronic nucleotide secretion, purinergic signaling and activation of inflammatory pathways. Purinergic signaling has been implicated in impaired glucose metabolism and inflammatory disease and may contribute to dyslipidemia. Our research shows that purinergic signaling disrupts hepatic lipoprotein metabolism by blocking insulin receptor signaling and by activating cellular autophagic pathways. Chronic stimulation of purinergic signaling may therefore be causative to glucose and lipid metabolic disorders and associated with the development of cardiovascular disease.
\end{abstract}

Copyright $@ 2012$ S. Karger AG, Basel

\section{Introduction}

While nucleotides are well known for their important role in intracellular energy metabolism, it is now established that they also play a role as extracellular messengers to modulate the immune and inflammatory response [1-3]. In healthy tissues, extracellular

Daniel L. Sparks, Ph.D.

University of Ottawa Heart Institute

40 Ruskin Street, Ottawa, Ontario, K1Y 4W7 (Canada)

Tel. +1 613 761-4822, Fax +1 613 761-5102, E-Mail dsparks@ottawaheart.ca 
nucleotide concentration is maintained at low concentrations to minimize purinergic signaling [4]. In fresh blood samples, nucleotide levels are normally in low $\mu \mathrm{M}$ concentrations [5, 6], but can increase both acutely and chronically in various disease states $[2,7,8]$. Extracellular nucleotide levels are controlled by cellular secretion and extracellular degradation. Nucleotide secretion is affected by intracellular $\left[\mathrm{Ca}^{2+}\right]$ and P2X7 [9]. The gated ion channel, P2X7 receptor, has been shown to stimulate nucleotide secretion and activate both the immune and inflammatory response $[3,10]$. High blood glucose levels directly stimulate the release of adenosine triphosphate (ATP) from endothelial tissues and circulating blood cells [11-13], but ATP is unstable in the circulation and is rapidly degraded to ADP, AMP and adenosine, by unique ecto-enzymes. Nucleotides are degraded by membrane ATP metabolizing proteins and specific ectonucleotidases, including NTPDase1, 2, 3, 8 (ATPase and ADPase) and CD73 (AMPase) [14, 15].The extracellular nucleotide milieu acts through specific P2X and P2Y receptors to promote a purinergic signaling response (Fig. 1). Shortlived nucleotide signaling may positively affect glucose metabolism by stimulating insulin secretion from pancreatic beta cells $[16,17]$. Sustained purinergic signaling appears to have the opposite effect and inhibits insulin receptor (IR- $\beta$ ) signaling $[18,19]$ and insulin secretion $[20,21]$. The acute release of nucleotides, by stress or injury, also activates nuclear factor kappa B [1,22] and triggers the release of pro-inflammatory cytokines [8, 23]. Chronic nucleotide signaling may therefore be involved in the pathophysiology of both metabolic and cardiovascular diseases $[2,24]$.

\section{Nucleotides and Disease}

Extracellular nucleotides are implicated in the development of coronary artery disease through a number of putative mechanisms $[2,7,25]$ and therapeutic inhibition of purinergic signaling has a well-established utility in the treatment of cardiovascular disease $[24,26]$. Nucleotides activate thrombosis pathways in the bloodstream and inhibition of nucleotidedependent platelet activation has shown significant cardiovascular therapeutic value [26, 27]. Abnormal nucleotide metabolism may also contribute to the development of type 2 diabetes (T2D), metabolic syndrome, and dyslipidemia. Fibroblasts from T2D patients show 2-3 fold increase in ATP secretion [28] and enhanced inflammatory and cytotoxic responses through the P2X7 receptor [29]. P2X7 expression appears to be elevated in peripheral blood mononuclear cells from T2D patients and significantly correlated with LDL-cholesterol [30]. Adipocyte P2X7 expression is elevated in patients with metabolic syndrome and associated with an enhanced inflammatory response [31]. Nucleotide degradation may also be impaired in diabetes, as polymorphisms in NTPDase1/CD39 are associated with T2D and diabetic nephropathy [32]. In vivo murine studies corroborate this view and show that a deficiency in CD39 can cause insulin resistance and hypertriglyceridemia [33]. Alterations in nucleotide secretion and/or degradation therefore appear to be associated with dyslipidemia, which suggests that purinergic signaling influences lipoprotein metabolism.

A role for extracellular nucleotides in plasma lipoprotein metabolism was proposed with the discovery of a plasma membrane form of $F_{1}$-ATP synthase, now called ecto- $F_{1}-$ ATP synthase or $\mathrm{F}_{1}$-ATPase. $\mathrm{F}_{1}$-ATPase was identified to be an HDL receptor that functions to bind with apoA-I and to regulate HDL endocytosis [34]. $\mathrm{F}_{1}$-ATPase was also shown to stimulate extracellular ADP production $[35,36]$ and promote purinergic signaling through the G-protein coupled receptor, $\mathrm{P}_{2} \mathrm{Y}_{13}[37,38] . \mathrm{F}_{1}$-ATPase is inhibited by mitochondrial inhibitory factor 1 (IF1) [34] and serum IF1 levels have been shown to be positively correlated with HDL-cholesterol levels and negatively correlated with serum triglyceride levels in normolipidemic subjects [39]. This is consistent with other work, which suggested that therapeutic modulation of circulating HDL levels may be associated with the expression of $\mathrm{F}_{1}$-ATPase, ADP production and purinergic signaling [19, 40, 41]. 


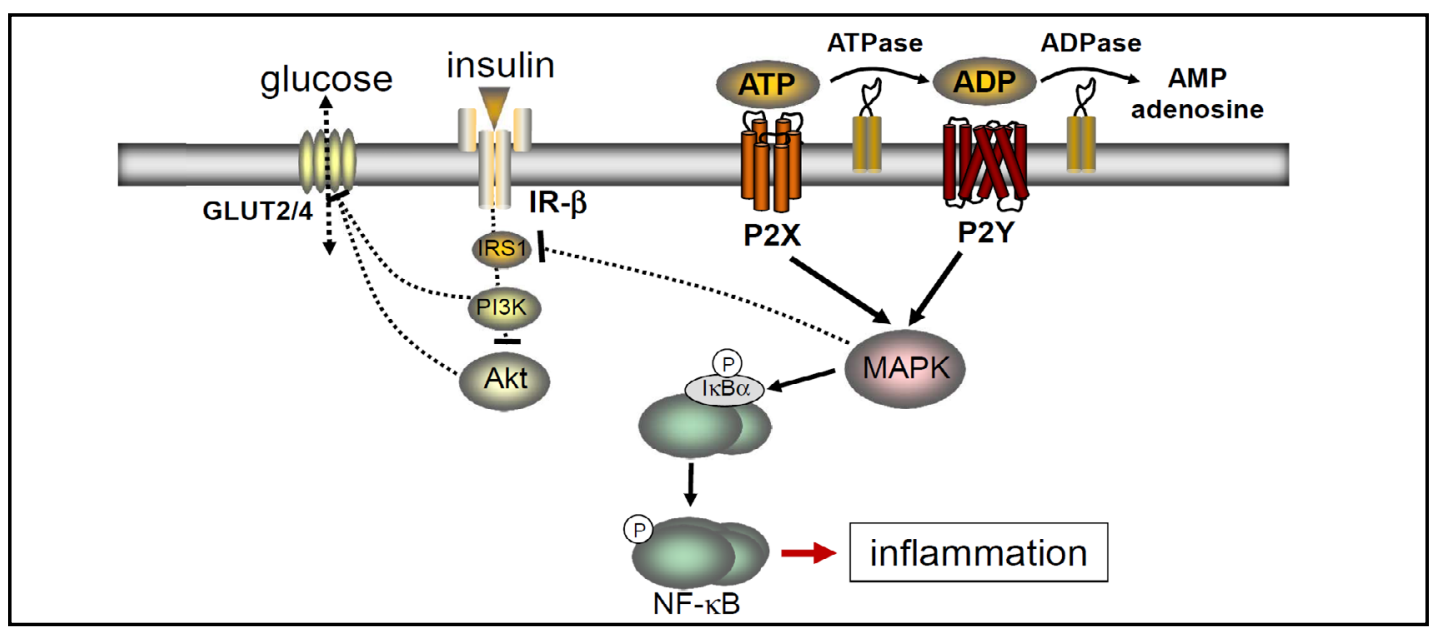

Fig. 1. Extracellular nucleotide levels are modulated by ecto-nucleotidases (ATPase and ADPase). Adenosine triphosphate (ATP) and adenosine diphosphate (ADP) act through P2X and P2Y receptors to promote inflammation by activation of mitogen-activated protein kinase (MAPK) and nuclear factor kappa B (NF- $\kappa$ B). Nucleotides can also affect glucose metabolic pathways by inhibiting insulin receptor- $\beta$ (IR- $\beta$ ) and protein kinase B (Akt) signaling.

\section{Nucleotides, Lipoproteins, and Cellular Protein Degradation}

Lipoprotein secretion is affected by proteolytic degradation pathways, which appear to be controlled by purinergic signaling [19]. Nucleotides therefore affect lipoprotein secretion by regulating intracellular protein degradation (Fig. 2). Pertubations in the lipidation or folding of the LDL protein, apoB100, result in the ubiquitination and transport of the protein for proteasomal degradation [42-44]. Inhibitors of proteasomal degradation are known to stimulate apoB100 secretion from liver cells and extracellular ADP acts much like a proteasomal inhibitor to affect lipoprotein secretion [19]. Both ADP and the proteasomal inhibitor, ALLN, stimulate apoB100 secretion and inhibit HDL secretion at $4 \mathrm{~h}$. This appears due to a co-regulation of proteasomal and autophagic protein degradation, since proteasomal inhibitors are known to stimulate autophagy [45-48]. Proteasomal inhibitors activate autophagy and increase expression of the autophagic proteins, Atg5, Beclin-1 and Atg7 [47, 48], which then gives rise to the transport and accumulation of Atg8/LC3 in autophagic vacuoles [45]. Much like proteasomal inhibitors, ADP also stimulates autophagy and significantly increases cellular LC3 levels [19].

Autophagy is a cellular stress response that promotes the lysosomal degradation of cytosolic components when stimulated by stressors, i.e. nutrient deprivation, extracellular signals, cytokines and pathogens $[49,50]$. ADP stimulates autophagy, increases autophagic protein levels and decreases HDL secretion from liver cells (Fig. 2) in similar fashion to that observed by serum deprivation [19]. Serum deprivation is known to stimulate autophagy $[49,50]$ and to inhibit HDL/apoA-I secretion from liver cells [51]. Both ADP and serum deprivation stimulate an autophagic response in hepatic cells and increase LC3-II and p62 levels over a three to six hour period. Confocal micrographs of ADP-treated liver cells show increased LC3 levels in punctate autophagosomes and significant colocalization of apoA-I with LC3 [19]. The work shows that HDL secretion from liver cells is inhibited by cellular autophagic pathways, which may suggest that HDL secretion and lipidation are oppositely regulated by autophagy. Autophagy is also known to stimulate ABCA1-mediated cholesterol efflux from macrophages and promote the transport and clearance of cholesterol [52]. 


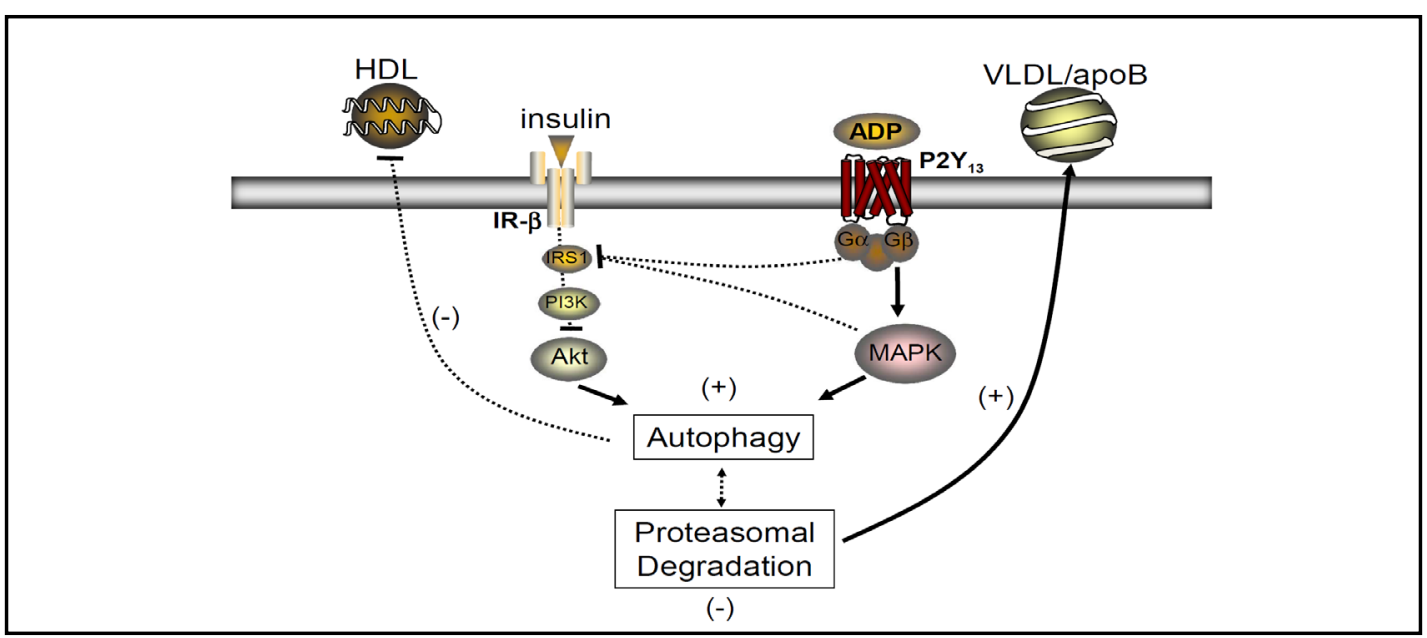

Fig. 2. Extracellular nucleotides act through $P 2 \mathrm{Y}_{13}$ receptors to activate $\mathrm{MAPK}$, inhibit Akt and regulate cellular proteolytic pathways. A purinergic stimulation in autophagy blocks HDL secretion from liver cells and stimulates VLDL-apoB secretion.

\section{Purinergic Signaling and Autophagy}

Extracellular nucleotides act through membrane P2 receptors to stimulate purinergic signaling. ADP activates the P2Y receptor class and affects cellular metabolism through a stimulation of mitogen-activated protein kinase (MAPK) and inhibition of adenylate cyclase [53]. Lipoprotein secretion is directly affected by MAPK, but is less sensitive to cAMPdependent pathways, since chemical inhibition of adenylate cyclase had no effect on HDL secretion, while blocking MAPK pathways affects both autophagy and HDL secretion [19]. MAPK signaling is known to affect cellular autophagy [50] and ADP directly stimulates MAPK pathways $[19,37,54]$. Insulin receptor (IR- $\beta$ ) signaling is also known to regulate cellular autophagic pathways [49] and ADP inhibits IR- $\beta$ signaling [19]. IR- $\beta$ signaling is negatively associated with autophagy, since the phosphorylation of protein kinase B (Akt) has been shown to inhibit autophagy $[49,55]$. ADP blocks insulin signaling and reduces both IR- $\beta$ and Akt phosphorylation by $\sim 50 \%$, similar to that observed with tumor necrosis factor alpha. ADP therefore regulates autophagy and lipoprotein secretion through both MAPK and Akt signaling pathways (Fig. 2).

Human liver cells contain two ADP-receptors, $\mathrm{P} 2 \mathrm{Y}_{1}$ and $\mathrm{P}_{2} \mathrm{Y}_{13}$, but lipoprotein metabolism appears to be primarily affected by $\mathrm{P}_{2} \mathrm{Y}_{13}[37,54,56]$. Chemical inhibitors of P2Y ${ }_{1}$ have no effect on HDL secretion, while modulation of $\mathrm{P}_{2} \mathrm{Y}_{13}$ expression directly affects HDL secretion from liver cells. $\mathrm{P}_{2} \mathrm{Y}_{13}$ overexpression increases cellular LC3-II levels and decreases HDL secretion, while $\mathrm{P} \mathrm{Y}_{13}$ gene silencing decreases LC3-II levels and increases HDL secretion [19]. Consistent with the view that $\mathrm{P}_{2} \mathrm{Y}_{13}$ expression regulates HDL secretion through cellular autophagic signaling pathways, $\mathrm{P} 2 \mathrm{Y}_{13}$ expression also regulates both MAPK and Akt signaling. A reduction in $\mathrm{P}_{2} \mathrm{Y}_{13}$ expression causes a parallel reduction in ERK1/2 phosphorylation, but increases the phosphorylation of IR- $\beta$, IGF-1R and Akt. Increasing $\mathrm{P}_{2} \mathrm{Y}_{13}$ expression has the opposite effect. Nucleotide signaling through $\mathrm{P}_{2} \mathrm{Y}_{13}$ therefore blocks insulin receptor signaling [19] (Fig. 1).

\section{Conclusion}

Lipoprotein metabolism is directly affected by nucleotides and cellular autophagy and therefore inhibition of hepatic purinergic signaling should directly affect circulating lipoprotein levels. Niacin may impact cardiovascular disease and lipoprotein metabolism through purinergic and G-protein coupled signaling pathways $[40,57,58]$. Niacin has been 
shown to increase circulating HDL levels by blocking hepatic apoA-I degradation [59]. Niacin reduces cell surface levels of $F_{1}$-ATPase in hepatocytes and thereby blocks the production of extracellular ADP [40]. Linoleic acid phospholipids also block ADP production by inhibiting the cell surface expression of $\mathrm{F}_{1}$-ATPase and thereby stimulate HDL secretion from liver cells [41]. These phospholipids appear to mute purinergic signaling and cellular autophagy by stimulating Akt phosphorylation and blocking MAPK activation [19]. An activation of Akt and inhibition of autophagy may therefore be important in increasing plasma HDL levels. Metformin and sulfonylurea drugs are popular anti-diabetic drugs that have been well described to reduce plasma glucose levels and improve circulating HDL and triglycerides [60]. Both classes of drugs are known to stimulate Akt phosphorylation and may therefore also block cellular autophagy [61,62]. This may suggest that augmentation of insulin receptor signaling and inhibition of cellular autophagy may positively affect both glucose and lipoprotein metabolism. This dual metabolic property may represent a common mechanistic feature of both the insulin-sensitizing drugs and some therapeutics that are utilized to treat patients with disorders in lipid metabolism.

\section{Abbreviations}

ADP (adenosine diphosphate); Akt (protein kinase B); apoA-I (apolipoprotein A-I); ATP (adenosine triphosphate); CD73 (ecto-5'-nucleotidase); $\mathrm{F}_{1}$-ATP synthase ( $\mathrm{F}_{1}$-ATPase); HDL (high density lipoprotein); IF1 (mitochondrial inhibitory factor 1); IR- $\beta$ (insulin receptor $\beta$ ); LC3 (microtubule-associated protein 1 light chain 3); LDL (low density lipoprotein); MAPK (mitogen-activated protein kinase); NF- $\mathrm{B}$ (nuclear factor kappa B); NTPDase (nucleoside triphosphate diphosphohydrolase); P2X (ion channel purinergic receptor); P2Y (G-proteincoupled purinergic receptor); T2D (type 2 diabetes).

\section{References}

1 von Albertini M, Palmetshofer A, Kaczmarek E, Koziak K, Stroka D, Grey ST, Stuhlmeier KM, Robson SC: Extracellular ATP and ADP activate transcription factor NF-kappa B and induce endothelial cell apoptosis. Biochem Biophys Res Commun 1998;248:822-829.

1 DiVirgilio F, Solini A: P2 receptors: new potential players in atherosclerosis. Br J Pharmacol 2002;135:831842 .

-3 DiVirgilio F, Boeynaems JM, Robson SC: Extracellular nucleotides as negative modulators of immunity. Curr Opin Pharmacol 2009;9:507-513.

$\checkmark 4$ Dwyer KM, Deaglio S, Gao W, Friedman D, Strom TB, Robson SC: CD39 and control of cellular immune responses. Purinergic Signal 2007;3:171-180.

-5 Brown PR, Parks RE, Jr., Herod J: Use of high-pressure liquid chromatography for monitoring nucleotide concentration in human blood: a preliminary study with stored blood cell suspensions. Clin Chem 1973;19:919-922.

6 Harkness RA, Coade SB, Webster AD: ATP, ADP and AMP in plasma from peripheral venous blood. Clin Chim Acta 1984;143:91-98.

7 Erlinge D, Burnstock G: P2 receptors in cardiovascular regulation and disease. Purinergic Signal 2008;4:120.

8 Trautmann A: Extracellular ATP in the immune system: more than just a "danger signal". Sci Signal 2009;2:e6.

$\checkmark 9$ Lohman AW, Billaud M, Isakson BE: Mechanisms of ATP release and signalling in the blood vessel wall. Cardiovasc Res 2012;95:269-280.

10 Bours MJ, Dagnelie PC, Giuliani AL, Wesselius A, DiVirgilio F: P2 receptors and extracellular ATP: a novel homeostatic pathway in inflammation. Front Biosci (Schol Ed) 2011;3:1443-1456.

11 Parodi J, Flores C, Aguayo C, Rudolph MI, Casanello P, Sobrevia L: Inhibition of nitrobenzylthioinosinesensitive adenosine transport by elevated D-glucose involves activation of P2Y2 purinoceptors in human umbilical vein endothelial cells. Circ Res 2002;90:570-577.

12 Solini A, Iacobini C, Ricci C, Chiozzi P, Amadio L, Pricci F, Di MU, DiVirgilio F, Pugliese G: Purinergic modulation of mesangial extracellular matrix production: role in diabetic and other glomerular diseases. Kidney Int 2005;67:875-885. 
13 Nilsson J, Nilsson LM, Chen YW, Molkentin JD, Erlinge D, Gomez MF: High glucose activates nuclear factor of activated T cells in native vascular smooth muscle. Arterioscler Thromb Vasc Biol 2006;26:794-800.

14 Kukulski F, Levesque SA, Sevigny J: Impact of ectoenzymes on p2 and p1 receptor signaling. Adv Pharmacol 2011;61:263-299.

15 Deaglio S, Robson SC: Ectonucleotidases as regulators of purinergic signaling in thrombosis, inflammation, and immunity. Adv Pharmacol 2011;61:301-332.

16 Bertrand G, Chapal J, Puech R, Loubatieres-Mariani MM: Adenosine-5'-0-(2-thiodiphosphate) is a potent agonist at $\mathrm{P} 2$ purinoceptors mediating insulin secretion from perfused rat pancreas. Br J Pharmacol 1991;102:627-630.

17 Fernandez-Alvarez J, Hillaire-Buys D, Loubatieres-Mariani MM, Gomis R, Petit P: P2 receptor agonists stimulate insulin release from human pancreatic islets. Pancreas 2001;22:69-71.

18 Mistafa O, Hogberg J, Stenius U: Statins and ATP regulate nuclear pAkt via the P2X7 purinergic receptor in epithelial cells. Biochem Biophys Res Commun 2008;365:131-136.

19 Chatterjee C, Sparks DL: Extracellular nucleotides inhibit insulin receptor signaling, stimulate autophagy and control lipoprotein secretion. PLoS ONE 2012;7:e36916.

20 Tan C, Salehi A, Svensson S, Olde B, Erlinge D: ADP receptor P2Y(13) induce apoptosis in pancreatic betacells. Cell Mol Life Sci 2010;67:445-453.

21 Amisten S, Meidute-Abaraviciene S, Tan C, Olde B, Lundquist I, Salehi A, Erlinge D: ADP mediates inhibition of insulin secretion by activation of P2Y13 receptors in mice. Diabetologia 2010;53:1927-1934.

22 Aga M, Watters JJ, Pfeiffer ZA, Wiepz GJ, Sommer JA, Bertics PJ: Evidence for nucleotide receptor modulation of cross talk between MAP kinase and NF-kappa B signaling pathways in murine RAW 264.7 macrophages. Am J Physiol Cell Physiol 2004;286:C923-C930.

-23 Khakh BS, North RA: P2X receptors as cell-surface ATP sensors in health and disease. Nature 2006;442:527-532.

-24 Sellers MB, Tricoci P, Harrington RA: A new generation of antiplatelet agents. Curr Opin Cardiol 2009;24:307-312.

25 Chinellato A, Ragazzi E: Receptor-mediated pathways of endothelium activity in experimental atherosclerosis. Pharmacol Res 1995;31:163-168.

26 Bailey AL, Campbell CL: Oral antiplatelet therapy for acute coronary syndromes: aspirin, P2Y12 inhibition and thrombin receptor antagonists. Curr Drug Targets 2011;12:1805-1812.

27 Watala C: Blood platelet reactivity and its pharmacological modulation in (people with) diabetes mellitus. Curr Pharm Des 2005;11:2331-2365.

28 Solini A, Chiozzi P, Morelli A, Passaro A, Fellin R, DiVirgilio F: Defective P2Y purinergic receptor function: A possible novel mechanism for impaired glucose transport. J Cell Physiol 2003;197:435-444.

29 Solini A, Chiozzi P, Morelli A, Adinolfi E, Rizzo R, Baricordi OR, DiVirgilio F: Enhanced P2X7 activity in human fibroblasts from diabetic patients: a possible pathogenetic mechanism for vascular damage in diabetes. Arterioscler Thromb Vasc Biol 2004;24:1240-1245.

-30 Garcia-Hernandez MH, Portales-Cervantes L, Cortez-Espinosa N, Vargas-Morales JM, Fritche Salazar JF, Rivera-Lopez E, Rodriguez-Rivera JG, Quezada-Calvillo R, Portales-Perez DP: Expression and function of P2X(7) receptor and CD39/Entpd1 in patients with type 2 diabetes and their association with biochemical parameters. Cell Immunol 2011;269:135-143.

-31 Madec S, Rossi C, Chiarugi M, Santini E, Salvati A, Ferrannini E, Solini A: Adipocyte P2X7 receptors expression: a role in modulating inflammatory response in subjects with metabolic syndrome? Atherosclerosis 2011;219:552-558.

-32 Friedman DJ, Talbert ME, Bowden DW, Freedman BI, Mukanya Y, Enjyoji K, Robson SC: Functional ENTPD1 polymorphisms in African Americans with diabetes and end-stage renal disease. Diabetes 2009;58:9991006.

-33 Enjyoji K, Kotani K, Thukral C, Blumel B, Sun X, Wu Y, Imai M, Friedman D, Csizmadia E, Bleibel W, Kahn BB, Robson SC: Deletion of cd39/entpd1 results in hepatic insulin resistance. Diabetes 2008;57:2311-2320.

-34 Martinez LO, Jacquet S, Esteve JP, Rolland C, Cabezon E, Champagne E, Pineau T, Georgeaud V, Walker JE, Terce F, Collet X, Perret B, Barbaras R: Ectopic beta-chain of ATP synthase is an apolipoprotein A-I receptor in hepatic HDL endocytosis. Nature 2003;421:75-79.

-35 Radojkovic C, Genoux A, Pons V, Combes G, de JH, Champagne E, Rolland C, Perret B, Collet X, Terce F, Martinez LO: Stimulation of cell surface F1-ATPase activity by apolipoprotein A-I inhibits endothelial cell apoptosis and promotes proliferation. Arterioscler Thromb Vasc Biol 2009;29:1125-1130.

-36 Cavelier C, Ohnsorg PM, Rohrer L, von EA: The beta-chain of cell surface F(0)F(1) ATPase modulates apoA-I and HDL transcytosis through aortic endothelial cells. Arterioscler Thromb Vasc Biol 2012;32:131-139.

-37 Jacquet S, Malaval C, Martinez LO, Sak K, Rolland C, Perez C, Nauze M, Champagne E, Terce F, Gachet C, Perret B, Collet X, Boeynaems JM, Barbaras R: The nucleotide receptor P2Y13 is a key regulator of hepatic high-density lipoprotein (HDL) endocytosis. Cell Mol Life Sci 2005;62:2508-2515.

38 Fabre AC, Vantourout P, Champagne E, Terce F, Rolland C, Perret B, Collet X, Barbaras R, Martinez LO: Cell surface adenylate kinase activity regulates the F(1)-ATPase/P2Y (13)-mediated HDL endocytosis pathway on human hepatocytes. Cell Mol Life Sci 2006;63:2829-2837. 
-39 Genoux A, Pons V, Radojkovic C, Roux-Dalvai F, Combes G, Rolland C, Malet N, Monsarrat B, Lopez F, Ruidavets JB, Perret B, Martinez LO: Mitochondrial inhibitory factor 1 (IF1) is present in human serum and is positively correlated with HDL-cholesterol. PLoS One 2011;6:e23949.

40 Zhang LH, Kamanna VS, Zhang MC, Kashyap ML: Niacin inhibits surface expression of ATP synthase \{beta\} chain in HepG2 cells: implications for raising HDL. J Lipid Res 2008;49:1195-1201.

-41 Pandey NR, Renwick J, Rabaa S, Misquith A, Kouri L, Twomey E, Sparks DL: An induction in hepatic HDL secretion associated with reduced ATPase expression. Am J Pathol 2009;175:1777-1787.

42 Fisher EA, Zhou MY, Mitchell DM, Wu XJ, Omura S, Wang HX, Goldberg AL, Ginsberg HN: The degradation of apolipoprotein B100 is mediated by the ubiquitin-proteasome pathway and involves heat shock protein 70 . J Biol Chem 1997;272:20427-20434.

-43 Adeli K, Macri J, Mohammadi A, Kito M, Urade R, Cavallo D: Apolipoprotein B is intracellularly associated with an ER-60 protease homologue in HepG2 cells. J Biol Chem 1997;272:22489-22494.

-44 Rutledge AC, Qiu W, Zhang R, Kohen-Avramoglu R, Nemat-Gorgani N, Adeli K: Mechanisms targeting apolipoprotein B100 to proteasomal degradation: evidence that degradation is initiated by BiP binding at the $\mathrm{N}$ terminus and the formation of a p97 complex at the $\mathrm{C}$ terminus. Arterioscler Thromb Vasc Biol 2009;29:579-585.

45 Ding WX, Ni HM, Gao W, Yoshimori T, Stolz DB, Ron D, Yin XM: Linking of autophagy to ubiquitinproteasome system is important for the regulation of endoplasmic reticulum stress and cell viability. Am J Pathol 2007;171:513-524.

46 Wu WK, Wu YC, Yu L, Li ZJ, Sung JJ, Cho CH: Induction of autophagy by proteasome inhibitor is associated with proliferative arrest in colon cancer cells. Biochem Biophys Res Commun 2008;374:258-263.

47 Zhu K, Dunner K, Jr., McConkey DJ: Proteasome inhibitors activate autophagy as a cytoprotective response in human prostate cancer cells. Oncogene 2010;29:451-462.

-48 Wu WK, Cho CH, Lee CW, Wu YC, Yu L, Li ZJ, Wong CC, Li HT, Zhang L, Ren SX, Che CT, Wu K, Fan D, Yu J, Sung JJ: Macroautophagy and ERK phosphorylation counteract the antiproliferative effect of proteasome inhibitor in gastric cancer cells. Autophagy 2010;6:228-238.

49 Kroemer G, Marino G, Levine B: Autophagy and the integrated stress response. Mol Cell 2010;40:280-293.

50 Ravikumar B, Sarkar S, Davies JE, Futter M, Garcia-Arencibia M, Green-Thompson ZW, Jimenez-Sanchez M, Korolchuk VI, Lichtenberg M, Luo S, Massey DC, Menzies FM, Moreau K, Narayanan U, Renna M, Siddiqi FH, Underwood BR, Winslow AR, Rubinsztein DC: Regulation of mammalian autophagy in physiology and pathophysiology. Physiol Rev 2010;90:1383-1435.

-51 Ranganathan S, Kottke BA: Rapid regulation of apolipoprotein A-I secretion in HepG2 cells by a factor associated with bovine high-density lipoproteins. Biochim Biophys Acta Lipids Lipid Metab 1990;1046:223-228.

52 Ouimet M, Franklin V, Mak E, Liao X, Tabas I, Marcel YL: Autophagy regulates cholesterol efflux from macrophage foam cells via lysosomal acid lipase. Cell Metab 2011;13:655-667.

53 Boeynaems JM, Communi D, Gonzalez NS, Robaye B: Overview of the P2 receptors. Semin Thromb Hemost 2005;31:139-149.

-54 Malaval C, Laffargue M, Barbaras R, Rolland C, Peres C, Champagne E, Perret B, Terce F, Collet X, Martinez LO: RhoA/ROCK I signalling downstream of the P2Y13 ADP-receptor controls HDL endocytosis in human hepatocytes. Cell Signal 2009;21:120-127.

55 Verfaillie T, Salazar M, Velasco G, Agostinis P: Linking ER Stress to Autophagy: Potential Implications for Cancer Therapy. Int J Cell Biol 2010;2010:930509.

-56 Schofl C, Ponczek M, Mader T, Waring M, Benecke H, von zur MA, Mix H, Cornberg M, Boker KH, Manns MP, Wagner S: Regulation of cytosolic free calcium concentration by extracellular nucleotides in human hepatocytes. Am J Physiol 1999;276:G164-G172.

57 Li G, Shi Y, Huang H, Zhang Y, Wu K, Luo J, Sun Y, Lu J, Benovic JL, Zhou N: Internalization of the human nicotinic acid receptor GPR109A is regulated by G(i), GRK2, and arrestin3. J Biol Chem 2010;285:2260522618.

58 Lukasova M, Malaval C, Gille A, Kero J, Offermanns S: Nicotinic acid inhibits progression of atherosclerosis in mice through its receptor GPR109A expressed by immune cells. J Clin Invest 2011;121:1163-1173.

-59 Jin FY, Kamanna VS, Kashyap ML: Niacin decreases removal of high-density lipoprotein apolipoprotein A-I but not cholesterol ester by Hep G2 cells - Implication for reverse cholesterol transport. Arterioscler Tromb Vasc Biol 1997;17:2020-2028.

60 Marena S, Tagliaferro V, Montegrosso G, Pagano A, Scaglione L, Pagano G: Metabolic effects of metformin addition to chronic glibenclamide treatment in type 2 diabetes. Diabete Metab 1994;20:15-19.

61 Jojima T, Suzuki K, Hirama N, Uchida K, Hattori Y: Glimepiride upregulates eNOS activity and inhibits cytokine-induced NF-kappaB activation through a phosphoinoside 3-kinase-Akt-dependent pathway. Diabetes Obes Metab 2009;11:143-149.

62 Ben S, I, Tanti JF, Bost F: The combination of metformin and 2 deoxyglucose inhibits autophagy and induces AMPK-dependent apoptosis in prostate cancer cells. Autophagy 2010;6. [Epub ahead of print]. 